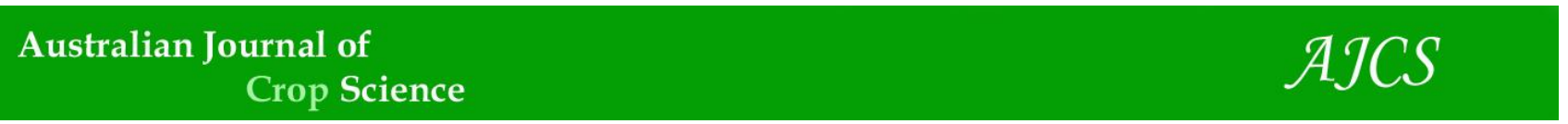

AJCS 14(11):1817-1825 (2020)

ISSN:1835-2707

doi: 10.21475/ajcs.20.14.11.p2360

\title{
Morphophysiological traits of soybean leaflets and their relationship with crop agronomic performance
}

\author{
Carlos André Bahry ${ }^{1 *}$, Ângela Aparecida Carleso ${ }^{1}$, Anelise Tessari Perboni ${ }^{1}$, Françoá Santos Dal Prá ${ }^{1}$, \\ Gelson Geraldo ${ }^{1}$, Leandro André Petkowicz ${ }^{1}$, Leocádio Ceresoli ${ }^{1}$, Américo Wagner Junior $^{1}$ and José \\ Abramo Marchese ${ }^{2}$
}

\author{
${ }^{1}$ Universidade Tecnológica Federal do Paraná (UTFPR), Câmpus Dois Vizinhos, Estrada para Boa Esperança, Km 04, \\ Dois Vizinhos, Paraná, Brazil. 85.660-000 \\ ${ }^{2}$ Universidade Tecnológica Federal do Paraná (UTFPR), Câmpus Pato Branco, Via do Conhecimento, Km 01, Pato \\ Branco, Paraná, Brazil. 85503-390
}

\section{*Corresponding author: carlosbahry@utfpr.edu.br}

\begin{abstract}
Soybean genotypes have distinct morphophysiological traits, which may influence the crop agronomic performance. The aim of this work was to evaluate the productive parameters of three contrasting soybean genotypes for leaf morphophysiological traits. The experiment was carried out at in a typical Distroferric Red Latosol, located at latitude 2541'52" S and longitude 5303'94" W; in the 2015/16 (CY1) and 2016/17 (CY2) seasons. The genotypes tested were: BS 2601 RR $^{\circledR}$ (lanceolate and smaller leaflets); NS 6006 IPRO $^{\circledR}$ (triangular and intermediate leaflets) and homozygous lineage $\mathrm{Cl} 21$ IPRO ${ }^{\circledR}$ (oval and larger leaflets). The gas exchange, chlorophyll index, leaf area, leaflet length and width, and petiolulus length were evaluated when plants of each genotype were at the beginning of flowering. At harvest, the variables analyzed were: first pod insertion, plant height, number of pods and grains per plant, grains per pod, mass of one thousand grains and grain yield. The design used was randomized blocks with four replicates. Photosynthesis per leaf area unit was higher in $\mathrm{CY} 2$, and is related to greater stomatal conductance, higher chlorophyll index, lower transpiration and lower leaf area of plants. The lanceolate leaf cultivar showed higher grain yield due to the higher number of grains and the greater mass of these grains in the two crop years. In addition, it was the one that obtained lower leaf area and lower transpiration. The cultivar NS 6006 presented greater productive stability, but this trait does not confer greater productive potential.
\end{abstract}

Keywords: Glycine max., Phenotypic traits, Gas exchange, Productivity, Leaflet shape.

Abbreviations: A_net assimilation rate of $\mathrm{CO}_{2}$; Chla_chlorophyll $a$; Chlb_chlorophyll $b$; $\mathrm{CHIt}$ _total chlorophyll; $\mathrm{CE}_{-}$carboxylation efficiency; $\mathrm{Cfa}$ _humid subtropical mesothermal climate; $\mathrm{Ci}$ intercellular $\mathrm{CO}_{2}$ concentration; $\mathrm{CY} 1$ _crop year 1 ; $\mathrm{CY} 2$ _crop year 2; E_transpiration rate; FPI_first pod insertion; gs_stomatal conductance; GY_ grain yield; LA_leaf area; Llea_lenght leaflet; L/W_lenght/width; MTG_mass of one thousand grains; NGP_number of grains per plant; NPP_number of pods per plant; Wlea_width leaflet; WUE_efficiency in water use.

\section{Introduction}

Soybean is the most important oilseed in the world, especially as a source of protein and vegetable oil for the animal and human food industry (Sujata et al., 2011). The growing demand for crop grains has required, from breeding programs, the development of cultivars with higher yield potential.

One of the features that can be improved is the plant architecture, which includes stem height, branching pattern, leaf shape and position, and reproductive structures (Reinhardt and Kuhlemeier, 2002). Soybean cultivars have a great diversity of leaf types, with particularities in their orientation, size and shape of the leaflets (Huang et al., 2018). The format of the leaflets is considered a qualitative trait, which varies according to genotype, with most cultivars having large and oval leaflets (Krisnawati and Adie, 2017; Sujata et al., 2011).
In recent years, many genes that are involved in the developmental processes of leaf morphogenesis have been identified. The shape of lanceolate leaflets, for example, is a characteristic expressed by a single recessive gene, $I n$, which is also directly linked to the expression of the number of seeds per pod (Jeong et al., 2012). Lanceolate leaflets in soybeans are related to better plant architecture because their canopy arrangement results in a greater internal distribution of solar radiation. Thus, the leaves located in the lower layers are more favored by light penetration, and contribute more significantly to the assimilation of $\mathrm{CO}_{2}$ by the plant (Krisnawati and Adie, 2017).

The relationship between photosynthesis and grain yield in soybeans suggests that improving photosynthetic efficiency is a promising target for yield enhancement (Ainsworth et al., 2011). Solar radiation is also related to the main stem elongation and branching of soybean plants, leaf expansion, 
flowering induction, pod and grain setting, and biological fixation (Câmara, 2000).

In a study by Purcell et al. (2002), radiation use efficiency and soybean biomass production were evaluated in different plant populations. They observed that the light accumulated in soybean cultivation depends on the daily amount of photosynthetically active radiation, the number of days of accumulation and the amount of light intercepted daily by the plants. The efficiency of radiation use decreased with the increase of plant population, due to the shading between the leaves that caused the senescence of lower leaves. In this scenario, narrow leaflet soybean cultivars are more favorable for production at high plant densities, as opposed to broad leaflet cultivars that are more suitable for lower densities (Krisnawati and Adie, 2017).

Favoring light distribution along the plant canopy also can give to the soybean cultivars an advantage by minimizing the photodestructive effects of high irradiance on the upper leaf surface (Jiang et al., 2006). In addition, Lacerda (2007) points out that smaller leaves have less thick boundary air layers, which facilitates convective heat exchanges between the leaf and the air. This allows the leaf temperature to be reduced even when perspiration is very low.

When analyzing several Chinese soybean genotypes, Huang et al. (2018) verified that the plants of the lanceolate leaflets group presented higher height and number of nodes, not differing of cultivars with elliptic leaflets as to the mass of one hundred grains and the mass of grains per plant, and being superior to the group of rounded leaflets.

The aim of this work was to evaluate the productive parameters of three contrasting soybean genotypes for leaf morphophysiological traits, in two crop years.

\section{Results and discussion}

\section{Physiological parameters}

Initially, the analysis of variance was carried out in order to find differences for the physiological and morphological variables analyzed in the present study between the leaflets and their position (central, right and left) in the composite leaves of the three soybean cultivars, and the different crops. There was no significance due to the position of the leaflets (data not shown), therefore, the average of the three leaflets was considered for the comparison between soybean genotypes and crops years.

The analysis of variance of the data indicated interaction between the genotype $x$ crop years for the variables stomatal conductance (gs) and transpiration (E). The assimilation of $\mathrm{CO}_{2}(\mathrm{~A})$, intercellular carbon concentration (Ci), carboxylation efficiency (CE) and water use efficiency (WUE) were affected only by crop years.

The stomatal conductance observed in soybean leaflet was higher in the crop year 2 (CY2) than in the crop year 1 (CY1), for the three genotypes evaluated separately. When comparing gs within each crop, there was no difference between genotypes in CY1. Differently, in $\mathrm{CY} 2$, the highest gs occurred in cultivar NS 6006 (Table 1).

In relation to transpiration, this was higher in the CY1, comparing with $\mathrm{CY} 2$. However, for each material the genotype that presented the lowest transpiration was BS 2601, that presents lanceolate leaflets (Table 1).

Although soybean genotypes showed higher stomatal conductance in the $\mathrm{CY} 2$, the values of transpiration were lower than those presented in the CY1 (Table 1). During the period in which the transpiration of soybean leaflets was evaluated (9 a.m.-11 a.m.) in the CY1, the accumulated radiation was $4005 \mathrm{~W} \mathrm{~m}^{-2}$. In the $\mathrm{CY} 2$, this value was $1091 \mathrm{~W}$ $\mathrm{m}^{-2}$ (Gebiomet, 2018). In general, solar radiation in CY1 was higher (Figure 1).

According to Lacerda (2007), the greater intensity of solar radiation increases the need of transpiration to cool the leaves, since the evaporation of one gram of water of the leaf absorbs from 2.4 to $2.5 \mathrm{KJ}$ of energy. Thus, transpiration contributes to reduce leaf temperature, which is crucial during the day when it absorbs large amounts of solar energy.

The fact that the cultivar BS 2601 has transpired less than the others (Table 1) may be related to the lanceolate shape of its leaflets, and to the inclined angle that the leaves have in relation to the main stem, which minimizes their direct contact with the sunlight. This can also confer advantage to soybean cultivars with this trait, by minimizing the photodestructive effects of high irradiance on the leaf surface (Jiang et al., 2006).

The soybean genotypes showed higher photosynthetic rates in the $\mathrm{CY} 2$ (Table 2). The greater assimilation of $\mathrm{CO}_{2}$ was accompanied by the increase in the stomatal conductance of leaves of all genotypes (Table 1). According to Lacerda (2007), the increase of the stomatal conductance contributes to maximize the photosynthetic process, especially when the edaphoclimatic conditions are favorable to soybean.

Chavarria et al. (2015) studied soybean plants subjected to water restriction and observed that soil water potentials equal to or less than $-0.026 \mathrm{MPa}$ caused a significant reduction in soybean photosynthetic activity due to lower stomatal conductance, highlighting the relationship between the two factors.

According to Taiz and Zeiger (2017), leaves held vertically by the stem form a canopy that allows the contact of more leaves with the light and, in this way, they absorb the light energy in greater proportion, increasing the photosynthetic rates. The leaves shaded by others receive subsaturating photon fluxes, thus having lower photosynthetic rates.

Based on these leaf angulation traits, the equality of the photosynthetic rates between the lanceolate leaflet cultivar in relation to the intermediate and oval leaflet genotypes (Table 2), may be due to the fact that this analysis was performed in leaves of the upper third of the leaves plants. If this evaluation had contemplated leaves of the three thirds, distinct responses among the genotypes could have been observed.

The performance of $\mathrm{E}$ and photosynthetic rate in the $\mathrm{CY} 2$ (Tables 1 and 2, respectively), in which water loss was reduced and $\mathrm{CO}_{2}$ assimilation was higher, when compared to the previous crop, resulted in greater water use efficiency (WUE) (Table 2).

WUE is defined as the amount of carbon absorbed per unit of water used (Sinclair et al., 1984) and is a physiological parameter widely used to indicate vegetation performance (Medlyn, 2017). When evaluating the WUE of cultivars BR-16 (tolerant to water deficit) and Embrapa 48 (susceptible to water deficit), daily providing water to maintain soil at $40 \%$ of the field capacity. Catuchi et al. (2012) also observed reduced transpiration of cultivars, as well as increased WUE in this stress condition, which generated water savings for each assimilated $\mathrm{CO}_{2}$ molecule.

Despite the significance of variance analysis for intercellular carbon concentration (Ci) and carboxylation efficiency (CE) 
in the crop years factor, these variables did not differ among each other in the comparison of averages (Table 2).

The results observed regarding the assimilation of $\mathrm{CO}_{2}, \mathrm{Ci}$ and CE (Table 2) showed no difference between the evaluated genotypes. However, Castro et al. (2008) stated that soybean genotypes differ in photosynthetic potential, and genotypic variations linked to photosynthesis may be related to both the stomatal conductivity and the internal factors of the leaf, as resistance to the passage of $\mathrm{CO}_{2}$ in the mesophyll.

The analysis of variance for the indices of chlorophyll $a$ (chla), chlorophyll $b$ (chlb) and total chlorophyll (chlt) indicated that there was interaction between the genotypes tested and the crop years for the three variables in question. The chla index was higher in the CY2 compared to the CY1. In the comparison between genotypes in each crop year, in the CY1, the cultivar NS 6006 presented higher index of chla, followed by $\mathrm{BS} 2601$ and $\mathrm{Cl} 21$. In the $\mathrm{CY} 2$, the first two cultivars were equivalent, being higher in relation to lineage $\mathrm{Cl} 21$ (Table 3).

In relation to chlb, when comparing crop years, only the $\mathrm{Cl}$ 21 lineage presented a lower index in the CY1. When analyzing the variable within each crop year, in the CY1, BS 2601 cultivar (with more lanceolate leaflets) was superior, and the lowest value was observed in lineage $\mathrm{Cl} 21$. In the CY2, both genotypes were equal and superior to NS 6006 (Table 3).

Chlb plays an important role in plants, since it has the capacity to absorb energy at wavelengths different from chla, and transfer it to the reaction center, thus increasing energy capture in photochemical reactions (Kume et al., 2018).

For chlt, the result was higher in $\mathrm{CY} 2$ for the three genotypes. In the CY1, the highest values were observed in cultivars BS 2601 and NS 6006, with lanceolate and triangular leaflets, respectively, in comparison with the $\mathrm{Cl}$ lineage 21. Similar results were observed in $\mathrm{CY} 2$, when comparing the three genotypes (Table 3). According to Ludwig et al. (2016), chlorophyll is an intrinsic character of each genotype, but may vary depending on the management.

The lowest chlt content in the CY1 may be related to the greater intensity of accumulated rainfall until the evaluation of this variable (Figure 2). Even in well-structured soils with good drainage, when the moisture stays above the field capacity for prolonged periods, the air pores become occupied by water, reducing the root respiration and, consequently, decreasing the growth, the absorption of nutrients, nitrogen fixation, and the synthesis of cellular compounds such as chlorophyll (Lacerda et al., 2007).

In the present study, it was observed that, in addition to photosynthesis, chlt content was also higher in the CY2 (Tables 2 and 3, respectively). Gai et al. (2017) tested different nitrogen rates $\left(0,25,50,75 \mathrm{~kg} \mathrm{ha}^{-1}\right)$ applied at sowing, and verified an increase in the photosynthetic rates and chlorophyll content of soybean plants in the $V_{4}$ and $R_{2}$ stages, as well as increment in grain yield.

\section{Morphological parameters}

Regarding the petiole length, there was only statistical significance within each factor. This indicates that this structure is similar in size between the different cultivars and is little influenced by the environment, presenting 1.54 $\mathrm{cm}$ in average length.
In turn, for the variables length, width and length/width ratio of leaflets, and leaf area per plant, there was interaction between the genotype factors and crop years. Regarding the leaflet length between the years, the result was variable for each genotype. The cultivars BS 2601 and NS 6006 presented higher length in the CY1 compared to the $\mathrm{CY}$ 2. The $\mathrm{Cl} 21$ lineage (oval and larger leaflets) had an inverse response (Table 4).

When analyzing each crop year, in the first one, the BS 2601 cultivar had a longer leaflet length, followed by lineage $\mathrm{Cl} 21$ and NS 6006. In the $\mathrm{CY} 2$, lineage $\mathrm{Cl} 21$ had longer leaflets, with BS 2601 with intermediate length and NS 6006, again, with the lowest value observed for this variable (Table 4).

In the leaflet width variable, between the years, the cultivars BS 2601 and NS 6006 presented higher values compared to $\mathrm{CY} 2$. The opposite result was observed for the lineage $\mathrm{Cl} 21$. In the comparison of each year, the genotype that had the largest width in both years, it was lineage $\mathrm{Cl} 21$, followed by NS 6006 and BS 2601, the latter with the smallest leaflet width (Table 4).

The length and width of the leaflets have a strong influence on the genotype, however, suffer some effect of the environment causing small changes, without, however, drastically changing its format (Krisnawati and Adie, 2017). The format of the leaflets was attributed to a single gene, with dominant $(L n L n)$ and recessive $(L n I n)$ homozygous genotypes resulting in broad and narrow leaflets, respectively, and heterozygotes $(L n I n)$ in intermediate leaflets (Jeong et al., 2012). However, changes in leaf size depending on the environment may be related to water availability during its expansion. During this phase, when some stressor factor occurs, such as water deficit, this can cause limitation in cell division and expansion, compromising leaf growth (Lacerda, 2007).

According to Chen and Nelson (2004), the length/width ratio is the main parameter to determine the shape of soybean leaflets. In the present work, the cultivar BS 2601 showed the highest ratio in comparison to NS 6006 and $\mathrm{Cl} 21$, for both crop yields, which characterizes the lanceolate leaflet shape (Table 4).

The leaf area of the soybean cultivars did not differ in the first crop year between BS 2601 and NS 6006, with the lowest value in relation to the $\mathrm{Cl} 21$ lineage (oval and larger leaflet). In the $\mathrm{CY} 2$, the lowest value was again observed in BS 2601 (Table 5).

When analyzing the values of leaf area between the crop years, it was verified that in CY1, the leaf area of the genotypes was greater in relation to the $\mathrm{CY} 2$, except for the NS 6006, in which no difference was observed (Table 5). This higher value of leaf area in CY1 may be related to the greater availability of water, since the precipitation was superior to CY2 (Figure 2), conditioning a greater development of leaves.

In addition to higher water availability, according to Toledo et al. (2010), the increase of leaf area may be related to higher solar radiation, which was also higher in CY1 (Figure 1). It should be considered that increasing the leaf area above a certain point did not resulted in productivity gain due to leaves self-shading, which decreases photosynthetic rates of shaded leaves and stimulates early senescence, as well as increased respiratory rate, which reduces the net photosynthesis (Lopes and Lima, 2015). In this sense, more important than high leaf area indices is the maintenance of smaller but more efficient values (Corrêa, 2008). 
Table 1. Stomatal conductance (gs) and transpiration (E) as a function of the interaction between soybean genotypes and crop years.

\begin{tabular}{|c|c|c|c|c|}
\hline \multirow{2}{*}{ Genotypes } & \multicolumn{2}{|c|}{ gs $\left(\mathrm{mol} \mathrm{H}_{2} \mathrm{O} \mathrm{m}^{-2} \mathrm{~s}^{-1}\right)$} & \multicolumn{2}{|c|}{$\mathrm{E}\left(\mathrm{mmol} \mathrm{H} \mathrm{H}_{2} \mathrm{~m}^{-2} \mathrm{~s}^{-1}\right)$} \\
\hline & $\mathrm{CY} 1$ & $\mathrm{CY} 2$ & CY1 & $\mathrm{CY} 2$ \\
\hline BS 2601 & $1.01 \mathrm{aB}$ & $1.26 \mathrm{bA}$ & $9.88 \mathrm{cA}$ & $9.35 \mathrm{bB}$ \\
\hline NS 6006 & $1.03 \mathrm{aB}$ & $1.64 \mathrm{aA}$ & $10.58 \mathrm{bA}$ & $9.76 \mathrm{aB}$ \\
\hline Lineage $\mathrm{Cl} 21$ & $0.90 \mathrm{aB}$ & $1.42 \mathrm{bA}$ & $10.99 \mathrm{aA}$ & $9.80 \mathrm{aB}$ \\
\hline
\end{tabular}

*Averages followed by distinct letters, lower case letters in the column and upper case letters in lineage, differ by Duncan Test, at $5 \%$ probability. CY1: crop year 1; CY2: crop year 2.

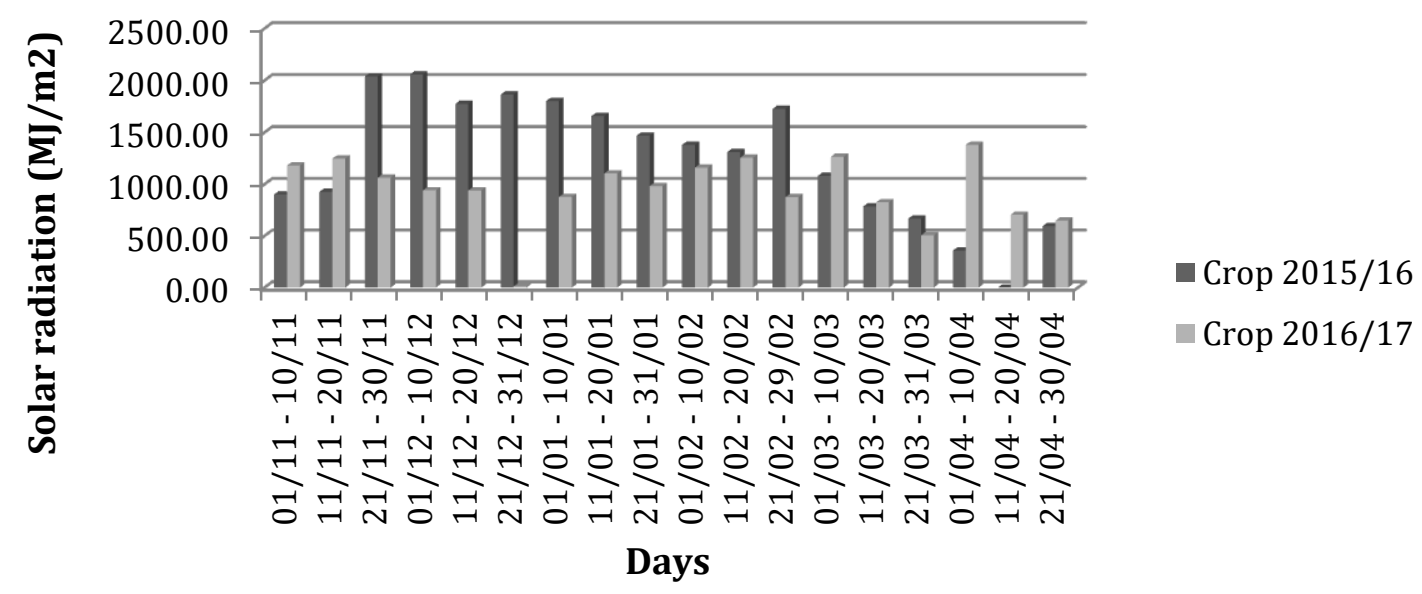

Figure 1. Average solar radiation in $\left(\mathrm{MJ} / \mathrm{m}^{2}\right)$ every ten days, from November to April of the two crop years, 2015/16 (crop year 1) and 2016/17 (crop year 2). Source: GEBIOMET (2018).

Table 2. Assimilation of $\mathrm{CO}_{2}$ (A), water use efficiency (WUE), intercellular carbon concentration (Ci) and carboxylation efficiency (CE) in soybean genotypes as a function of crop years.

\begin{tabular}{lcccc}
\hline $\mathrm{CY}$ & $\mathrm{A}\left(\mu \mathrm{mol} \mathrm{CO} \mathrm{m}^{-2} \mathrm{~s}^{-1}\right)$ & $\mathrm{WUE}$ & $\mathrm{Ci}\left(\mu \mathrm{mol} \mathrm{CO}_{2} \mathrm{~mol}^{-1}\right)$ & $\mathrm{CE}$ \\
\hline 1 & $22.13 \mathrm{~b}$ & $2.12 \mathrm{~b}$ & 311.52 & 0.0712 \\
2 & $24.59 \mathrm{a}$ & $2.58 \mathrm{a}$ & 319.57 & 0.0771 \\
\hline $\mathrm{CV}(\%)$ & 5.27 & 5.69 & 1.44 & 6.39 \\
\hline
\end{tabular}

*Averages followed by distinct letters differ from each other by the Duncan Test, at at 5\% probability. CY: crop year.
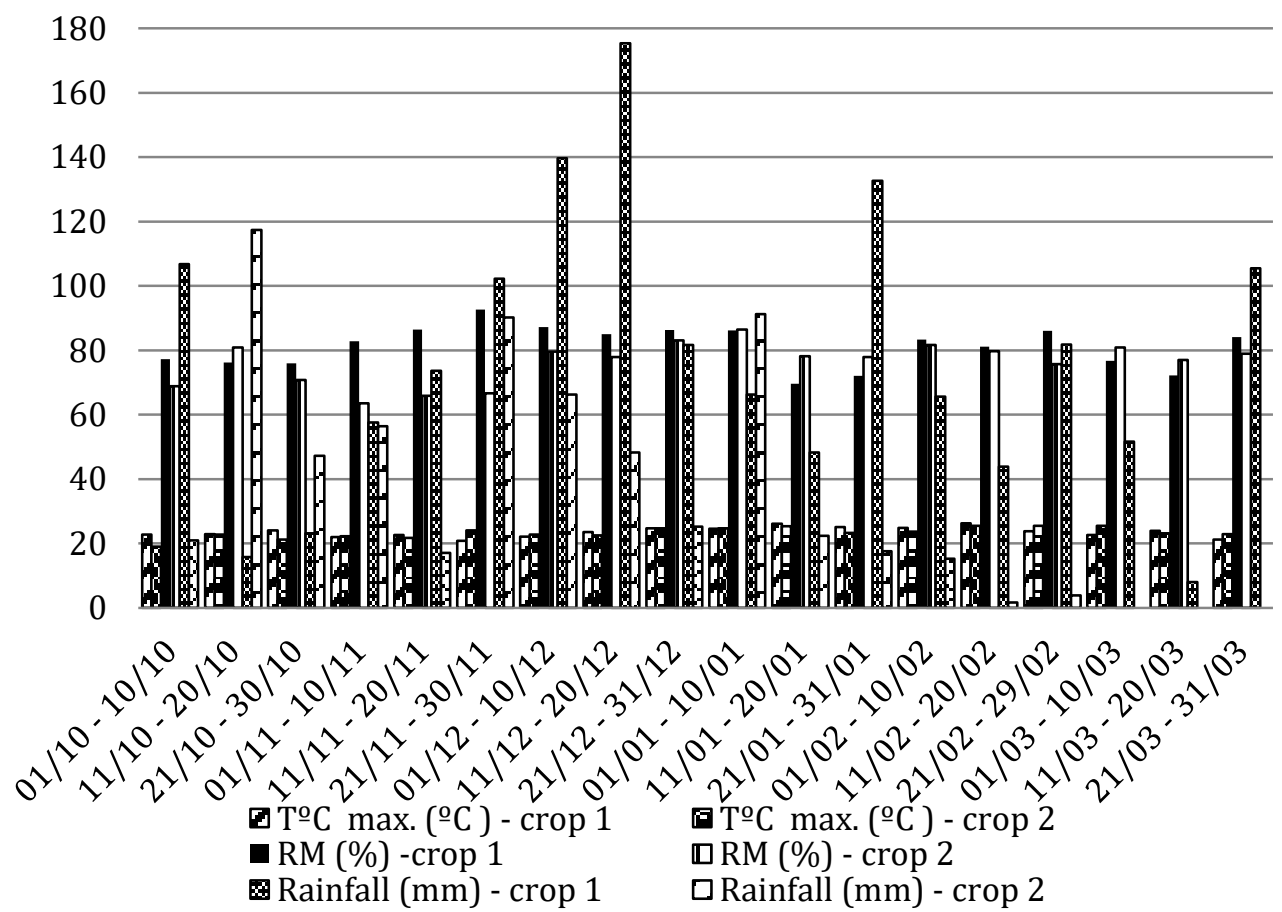

Figure 2: Maximum temperature $(\stackrel{\circ}{ } \mathrm{C})$, rainfall $(\mathrm{mm})$ and relative moisture (\%) between October and March, for the crop 1 (2015/16) and crop 2 (2016/17). Source: Gebiomet (2018). 
Table 3. Indices of chlorophyll $a$, chlorophyll $b$ and total chlorophyll as a function of the interaction between soybean genotypes and crop years.

\begin{tabular}{lcccccc}
\hline \multirow{2}{*}{ Genotype } & \multicolumn{2}{c}{ Chlorophyll $a$} & \multicolumn{2}{c}{ Chlorophyll $b$} & \multicolumn{2}{c}{ Total Chlorophyll } \\
\cline { 2 - 7 } & CY1 & CY2 & CY1 & CY2 & CY1 & CY2 \\
\hline BS 2601 & $45.01 \mathrm{bB}$ & $59.91 \mathrm{aA}$ & $9.97 \mathrm{aA}$ & $9.14 \mathrm{aB}$ & $54.98 \mathrm{aB}$ & $69.06 \mathrm{aA}$ \\
NS 6006 & $48.51 \mathrm{aB}$ & $59.66 \mathrm{aA}$ & $9.11 \mathrm{bA}$ & $7.39 \mathrm{bB}$ & $57.76 \mathrm{aB}$ & $67.04 \mathrm{abA}$ \\
Cl 21 & $40.59 \mathrm{cB}$ & $56.43 \mathrm{bA}$ & $7.83 \mathrm{CB}$ & $8.79 \mathrm{aA}$ & $48.42 \mathrm{bB}$ & $65.22 \mathrm{bA}$ \\
\hline CV (\%) & \multicolumn{3}{c}{3.48} & \multicolumn{3}{c}{2.82} \\
\hline
\end{tabular}

*Averages followed by distinct letters, lower case letters in the column and upper case in lineage, differ by Duncan Test, at $5 \%$ probability. CY1: crop year 1; CY2: crop year 2 .

Table 4. Length, width and length/width ratio of leaflets of soybean as a function of the interaction between genotypes and crop years.

\begin{tabular}{|c|c|c|c|c|c|c|}
\hline \multirow{2}{*}{ Genotypes } & \multicolumn{2}{|c|}{ Length $(\mathrm{cm})$} & \multicolumn{2}{|c|}{ Width $(\mathrm{cm})$} & \multicolumn{2}{|c|}{ Length/Width } \\
\hline & CY1 & $\mathrm{CY} 2$ & CY1 & $\mathrm{CY} 2$ & CY1 & $\mathrm{CY} 2$ \\
\hline BS 2601 & $13.0 \mathrm{aA}$ & $11.5 \mathrm{bB}$ & $6.3 \mathrm{cA}$ & $5.8 \mathrm{cB}$ & $2.1 \mathrm{aA}$ & $2.0 \mathrm{aB}$ \\
\hline NS 6006 & $11.7 \mathrm{cA}$ & $10.2 \mathrm{cB}$ & $7.9 \mathrm{bA}$ & $7.4 \mathrm{bB}$ & $1.5 \mathrm{bA}$ & $1.4 \mathrm{bB}$ \\
\hline Lineage $\mathrm{Cl} 21$ & $12.4 \mathrm{bB}$ & $13.0 \mathrm{aA}$ & $9.0 \mathrm{aB}$ & $9.5 \mathrm{aA}$ & $1.4 \mathrm{cA}$ & $1.4 \mathrm{bA}$ \\
\hline CV (\%) & \multicolumn{2}{|c|}{2.41} & \multicolumn{2}{|c|}{1.91} & \multicolumn{2}{|c|}{1.51} \\
\hline
\end{tabular}

*Averages followed by distinct letters, lower case letters in the column and upper case in lineage, differ by Duncan Test, at $5 \%$ probability. CY1: crop year 1; CY2: crop year 2.

Table 5. Leaf area $\left(\mathrm{cm}^{2}\right)$, per plant unit, as a function of the interaction between soybean genotypes and crop years.

\begin{tabular}{lcc}
\hline Genotypes & CY1 & CY2 \\
\hline BS 2601 & $1599.68 \mathrm{bA}$ & $814.10 \mathrm{bB}$ \\
NS 6006 & $2015.28 \mathrm{bA}$ & $1915.23 \mathrm{aA}$ \\
Lineage Cl 21 & $3294.83 \mathrm{aA}$ & $1987.13 \mathrm{aB}$ \\
\hline
\end{tabular}

CV (\%) 14.29

*Averages followed by distinct letters, lower case letters in the column and upper case in lineage, differ by Duncan Test, at $5 \%$ probability. CY1: crop year 1; CY2: crop year 2.

Table 6. Plant height (PH) according to the interaction between genotypes and crop years, and insertion of the first pod (FPI) and number of pods per plant (NPP) according to the crop years.

\begin{tabular}{lcc}
\hline \multirow{2}{*}{ Genotypes } & \multicolumn{3}{c}{ PH $(\mathrm{cm})$} & $\mathrm{CY2}$ \\
\cline { 2 - 3 } & $101.6 \mathrm{bB}$ & $110.9 \mathrm{bA}$ \\
BS 2601 & $96.1 \mathrm{cA}$ & $99.8 \mathrm{cA}$ \\
NS 6006 & $121.3 \mathrm{aB}$ & $151.5 \mathrm{aA}$ \\
Lineage Cl 21 & & \\
\hline CV (\%) & $\mathrm{FPl}(\mathrm{cm})$ & $\mathrm{NPP}$ \\
\hline Crop year & $16.3 \mathrm{~b}$ & $49.8 \mathrm{a}$ \\
\hline 1 & $25.5 \mathrm{a}$ & $36.7 \mathrm{~b}$ \\
\hline CV (\%) & 8.71 & 9.88 \\
\hline
\end{tabular}

*Averages followed by distinct letters, lower case letters in the column and upper case in lineage, differ by Duncan Test, at $5 \%$ probability. CY1: crop year 1; CY2: crop year 2.

Table 7. Number of grains per plant (NGP) and mass of one thousand grains (MTG) according to soybean genotypes and crop years.

\begin{tabular}{lcccc}
\hline \multirow{2}{*}{ Genotypes } & \multicolumn{3}{c}{ NGP } & \multicolumn{3}{c}{ MTG (g) } \\
\cline { 2 - 5 } BS 2601 & CY1 & CY2 & CY1 & CY2 \\
NS 6006 & $133.0 \mathrm{aA}$ & $96.4 \mathrm{aB}$ & $197.5 \mathrm{aA}$ & $170.7 \mathrm{aB}$ \\
Lineage Cl 21 & $103.1 \mathrm{bA}$ & $78.9 \mathrm{bB}$ & $170.1 \mathrm{bB}$ & $176.1 \mathrm{aA}$ \\
\hline CV (\%) & $127.9 \mathrm{aA}$ & $85.3 \mathrm{bB}$ & $155.5 \mathrm{cB}$ & $169.7 \mathrm{aA}$ \\
\hline
\end{tabular}
* Averages followed by distinct letters, lower case letters in the column and upper case in lineage, differ by Duncan Test, at $5 \%$ probability. CY1: crop year 1; CY2: crop year 2.

Table 8. Grain yield, adaptability and stability according to the tested genotypes.

\begin{tabular}{lcc}
\hline Genotypes & Grain yield $\left(\mathrm{kg} \mathrm{ha}^{-1}\right)$ & Adaptability and Stability - Wi (\%) \\
\hline BS 2601 & $4747.2 \mathrm{a}$ & 31.22 \\
NS 6006 & $4189.5 \mathrm{~b}$ & 5.57 \\
Lineage Cl 21 & $4193.9 \mathrm{~b}$ & 63.20 \\
\hline CV (\%) & 7.54 & -
\end{tabular}

\footnotetext{
*Averages followed by distinct letters, lowercase in the column, differ from each other by the Duncan Test, at $5 \%$ probability.
} Ecovalence (Wi). 
Table 9. Pearson correlation between physiological, morphological and productive parameters of soybean genotypes in two crop years.

\begin{tabular}{|c|c|c|c|c|c|c|c|c|}
\hline$P$ & A & $E$ & Llea & Wlea & L/W & LA & NGP & MTG \\
\hline$E$ & 0.087 & & & & & & & \\
\hline Llea & $-0.997^{*}$ & -0.014 & & & & & & \\
\hline Wlea & -0.127 & 0.976 & 0.199 & & & & & \\
\hline L/W & -0.302 & -0.975 & 0.232 & -0.906 & & & & \\
\hline LA & -0.115 & 0.979 & 0.187 & $0.999 *$ & -0.911 & & & \\
\hline NGP & $-0.997^{*}$ & -0.012 & 0.999* & 0.201 & 0.230 & 0.189 & & \\
\hline MTG & -0.021 & $-0.997 *$ & -0.051 & -0.988 & 0.959 & -0.990 & -0.053 & \\
\hline GY & -0.373 & -0.956 & 0.305 & -0.872 & $0.997^{*}$ & -0.878 & 0.303 & 0.935 \\
\hline
\end{tabular}

*Significance of the Pearson correlation coefficient was at $\mathrm{p}<0.05$. P: parameters; A_net assimilation rate of $\mathrm{CO}_{2}$; $\mathrm{E}_{-}$transpiration rate; Llea_lenght leaflet; Wlea_width leaflet; L/W_lenght/width; LA_leaf area; NGP_number of grains per plant MTG_mass of one thousand grains; GY_grain yield.

\section{Productivity parameters}

In the evaluation of parameters related to crop yield, analysis of variance indicated interaction between genotypes and crop years for plant height $(\mathrm{PH})$, number of grains per plant (NGP) and mass of one thousand grains (MTG). In addition, there was significance within the crop years factor, for the first pod insertion (FPI) and number of pods per plant (NPP). Within the genotype factor, significance was verified for grain yield.

The PH of the genotypes for each crop was higher in the IC 21 lineage, followed by BS 2601 and NS 6006. This behavior was verified in the two years of cultivation. In comparison, BS 2601 and lineage $\mathrm{Cl} 21$ presented a larger PH in the CY2. However, the cultivar NS 6006 maintained the same height pattern in the two harvests (Table 6).

The highest $\mathrm{PH}$ in the $\mathrm{CY} 2$ for two of the three evaluated genotypes may be related to the lower solar radiation incident this year in relation to the first one (Figure 1). In this case, plants tend to grow more in height in an attempt to intercept more solar radiation.

Analyzing the influence of shading on soybean plants, Yang et al. (2014) found that maize-soybean intercropping results in decreased photosynthetically active radiation in the canopy of soybean plants. This causes an increase in the height of soybean plants compared to monoculture plants. Cruz et al. (2016) found similar behavior in Anta 82 soybean cultivar, submitted to different plant arrangements.

Another important factor is the excess precipitation in the CY1 (Figure 2), which may have limited the root growth of the plants and, consequently, their growth in height, as well as the biological fixation, provided less $\mathrm{N}$ for the aerial part and reflecting in lower chlorophyll total content (Table 3 ).

This higher growth in plant height and investment of photoassimilates in the stems in $\mathrm{CY} 2$ may justify the lower values of leaf area of the genotypes in this crop year (Table 5). Such reduction in leaf area, in turn, may have been the cause of the maximization of the photosynthetic process per unit area to compensate for this limitation (Table 2), and to ensure that grain yield between the crop years was not affected (Table 8).

The height of the FPI showed a trend similar to plant height, being higher in the CY2 (Table 6). This relationship was also described by Campos et al. (2010) evaluating the architecture of soybean plants of cultivar BRS 184 sprayed with plant regulators in different stages, verified those plants showed higher growth in height also presented higher FPI.

Analyzing the NPP, it was higher in the CY1, independently of the genotype (Table 6). According to Liu et al. (2003), the high availability of irradiance over soybean plants at the beginning of flowering ( $R_{1}$ stage) increases the pods number per plant, reducing their abortion rate. This result obtained by Liu et al. (2003), agreed with the present study, since, in the CY1, the solar irradiance was higher than in the CY2 (Figure 1). In addition, plants that grow more in search of light (CY2) tend to produce fewer pods per plant. Cruz et al. (2016) also observed that the NPP was reduced as the height of soybean plants increased, since taller plants tended to have fewer branches.

The NGP, comparing the genotypes between them, for each crop year, presented variable results. In the $\mathrm{CY} 1$, the highest values were verified in cultivar BS 2601 and lineage $\mathrm{Cl}$ 21, which did not differ among them. In the CY2, BS 2601 remained higher, and the lowest averages were verified in NS 6006 and lineage $\mathrm{Cl} 21$ (Table 7). In the comparison between the crop years, the highest NGP occurred in the $\mathrm{CY} 1$, for the three genotypes evaluated.

Between years, the highest NGP occurred in the CY1 for the three genotypes (Table 7), as well as the largest NPP (Table 6). Some CY1 conditions contributed to the fact that soybean could fix more pods and grains per plant, among them the higher solar radiation (Figure 1), which conditioned the lower plants, which may have favored the photosynthetic process along the canopy of plants.

The mass of a thousand grains (MTG) was higher for BS 2601 in CY1. In the CY2, no difference was observed between the genotypes. When analyzing the years of cultivation, for each genotype, BS 2601 presented the highest MTG in the CY1. Instead, cultivar NS 6006 and lineage $\mathrm{Cl} 21$ had an inverse behavior, with a greater MTG in the CY2 (Table 7).

In general, there is an inverse relationship between NGP and MTG, as observed by Ludwig et al. (2011), which related the lowest NGP with higher MTG. That occurs because the reduction of the number of drains (grains) reduces the competition for photoassimilates, allowing a greater reserve accumulation inside them (Oliveira et al., 2017). However, in the present study, the cultivar BS 2601 (lanceolate leaflets), did not present this relation, that is, in both crops years, the greatest NGP did not cause a MTG reduction, being an important criterion to be analyzed by breeding programs.

The number of grains per pod had no influence of the studied factors. The mean verified was 2.37 grains per pod. This result is often observed in soybean, since the number of grains per pod is not so responsive to the production environment, but rather a genetic trait of the material, which contributes little to the phenotypic plasticity (Balbinot Júnior, 2018).

The grain yield was not influenced by the years of cultivation (Table 8). This may have occurred as a function of soybean plasticity, either by maximizing the photosynthetic process 
to compensate for the smaller leaf area in CY2 (Tables 2 and 5 , respectively) or by increasing grain mass (Table 7) in response to the reduction in the number of pods and grains per plant (Tables 6 and 7, respectively). The most productive genotype in this study, independent of the crop year, was BS 2601, of lanceolate leaflets. There was no difference in productivity between NS 6006 and $\mathrm{Cl} 21$ lineage (Table 8).

\section{Adaptability and productive stability}

In addition to evaluating the morphophysiological traits of leaflets and yield components to support the verified productivity results, an adaptability and stability analysis of the genotypes behavior was carried out in the two years of cultivation.

This analysis, following the method of Wricke (1965), identifies the superior performance cultivar, based on its productive mean and more predictable behavior among the years of cultivation (Franceschi et al., 2010). However, it should be noted that this method has greater applicability for productive stability of cultivars, with less relevance for adaptability.

Based on the results, it was verified that NS 6006 was the most stable genotype in both crop years, with lower ecovalence (Table 8 ), that is, it was the genotype with the lowest contribution to genotype vs environment interaction (Prado et al., 2001). The cultivar BS 2601 was considered intermediate and the lineage $\mathrm{Cl} 21$, the most unstable. This result of stability verified in the NS 6006 can be related to some traits analyzed in the present study that remained constant in both crop years, like the leaf area and the height of plant (Table 5 and 6), that were not verified in the other two materials.

However, not always a stable cultivar is the most productive, as verified in this study, in which the cultivar BS 2601 presented intermediate stability and greater productivity, independent of the crop year. When evaluating the adaptability and stability for grain yield in seventeen wheat cultivars, Franceschi et al. (2010) also observed, through the Wi method, that not all the more stable cultivars were those that obtained high yield of grains; since this trait can limit a larger range of response of cultivars to different environments.

The best potential of the BS 2601 genotype is also observed in maintaining in variable environmental conditions without significant changes in its physiological behavior. It should be noted that from $\mathrm{CY} 1$, with higher rainfall, to $\mathrm{CY} 2$, where the rainfall was lower, the genotypes NS 6006 and $\mathrm{Cl} 21$ decreased considerably the transpiration rates, while the genotype BS 2601 had a smaller reduction, maintaining the same photosynthetic rates as the others, without changes in productivity.

\section{Correlation between physiological, morphological and productive parameters}

The relationship between the physiological, morphological and productive parameters of soybean genotypes, regardless of the crop year, is observed in Table 9. Only the variables that correlated with each other are shown. Pearson's correlation coefficients revealed a negative correlation between A $x$ Llea $(r=-0,997), A \times N G P(r=-0,997)$ and $x$ MTG $(r=-0,997)$ and a positive correlation between Llea $\times$ NPG $(r=0,999)$, Wlea $\times$ LA $(r=0.999)$ and GY $\times$ L/W $(r$ $=0.997)$.
It was found that the longer the leaflets, the lower the $\mathrm{CO}_{2}$ assimilation values observed ( $\mathrm{x}$ Llea). The longer length of the leaflets is characteristic of narrower leaflets, which generally have greater inclination angles of the petioles in relation to the horizontal plane, as occurs with the narrow leaflets cultivar studied.

This arrangement of the leaflets, especially in the upper third of the plant where the A evaluation was performed, results in a lower direct light incidence when compared to the incidence that occurs in wider and less inclined leaflets, which may justify the inverse correlation between $A$ and Llea. At the whole plant level, such behavior would probably not be observed in the middle and lower thirds, as light penetration into the canopy of plants with narrow and slant leaflets would favor photosynthesis (Krisnawati and Adie, 2017). In addition, the leaflet width correlated positively with the leaf area (Wlea $\times$ LA), i.e., the larger leaf area of cultivars with wider and more horizontal leaflets can reduce light penetration at the base of the leaf plant.

The inverse correlation between A x NGP occurred because the narrowest leaflets presented the highest number of grains. Because they were more slanted and received less direct light than broad leaves, they possibly had less $\mathrm{CO}_{2}$ assimilation per unit area in the upper third. Assimilation evaluations in the three thirds could show the differences between genotypes regarding light penetration and photosynthesis.

Correlation analysis (Table 9) also showed that the largest Llea is related to the higher NGP. In addition, plants with reduced $E$ presented higher values of MTG. Cultivars with longer and narrower leaflets possibly had better light distribution along the canopy and, associated with higher NGP, lower E and higher MTG, achieved higher grain yield. Grain yield was directly related to the narrow shape of the leaflet $(G Y \times L)$, since the higher the length/width ratio of the leaflet, the greater the amount of grain produced per area in the present work.

\section{Materials and methods}

\section{Conducting the experiment}

The experiments were conducted in the experimental area of the Universidade Tecnológica Federal do Paraná (UTFPR), Câmpus Dois Vizinhos, Paraná, Brazil, in the 2015/16 (CY1) and 2016/17 (CY2). The altitude of the site is 509 meters, latitude 2541'52" S and longitude 5303'94" W. The climate is classified as Cfa - Humid subtropical mesothermal climate, with no defined dry season. The mean annual temperature is around 20 to 22 ㅇ C (lapar, 2009). The soil is classified as a Typical Dystroferric Red Latosol (Embrapa, 2006).

In each experiment, the design was randomized blocks with four replications. The genotypes studied were the cultivar BS $2601 \mathrm{RR}^{\circledast}$, with lanceolate leaflets, these being narrow and long (length $=12.29$; width $=6.01$ centimeters); the cultivar NS $6006 \mathrm{IPRO}^{\circledR}$, with intermediary leaflets of triangular shape (length $=10.92 ;$ width $=7.69$ centimeters); and the 21 $\mathrm{IPRO}^{\circledR}$ lineage, with leaflets of oval shape (length $=12.70$; width $=9.25$ centimeters), of greater size in comparison to previous ones.

Seeding under no-till system was carried out in the second fortnight of October, in both crop years. Each experimental plot was implanted with five-row seeders spaced $0,45 \mathrm{~m}$ and 3 meters long. 
The number of seeds per linear meter followed the traits of each genotype, according to the breeders' recommendation: $14 \mathrm{~m}^{-1}$ seeds were grown for BS $2601 \mathrm{RR}^{\circledR}, 15 \mathrm{~m}^{-1}$ seeds for NS 6006 IPRO $^{\circledR}$ and $10 \mathrm{~m}^{-1}$ seeds for IPRO ${ }^{\circledR} 21$ lineage.

\section{Traits measured}

Measurements of gas exchange and foliar chlorophyll index occurred in flowering plants, between stages $R_{1}$ and $R_{2}$ (beginning of flowering and full bloom, according to Fehr and Caviness, 1977), in young, healthy and fully expanded leaves. The readings were performed in four replicates, being recorded between 9 a.m. and 11 a.m.

For the gas exchanges an infrared gas analyzer (model LI6400XT LI-COR, Inc., Lincoln, NE, USA) was used, with a concentration of $\mathrm{CO}_{2}$ inside the chamber (model LI-COR 6400-11) of $400 \mathrm{\mu mol} \mathrm{mol}^{-1}$ and photon flux density of 1200 $\mu \mathrm{mol} \mathrm{m} \mathrm{m}^{-2}$, provided by light source (model LI-COR 640002). The variables evaluated were: net assimilation rate of $\mathrm{CO}_{2}\left(A, \mu \mathrm{mol} \mathrm{CO} \mathrm{m}^{-2} \mathrm{~s}^{-1}\right)$, stomatal conductance (gs, $\mathrm{mol} \mathrm{H}_{2} \mathrm{O}$ $\left.\mathrm{m}^{-2} \mathrm{~s}^{-1}\right)$, transpiration rate $\left(\mathrm{E}, \mathrm{mmol} \mathrm{H}_{2} \mathrm{O} \mathrm{m}^{-2} \mathrm{~s}^{-1}\right)$, intercellular $\mathrm{CO}_{2}$ concentration $\left(\mathrm{Ci}, \mu \mathrm{mol} \mathrm{CO}_{2}\right.$ mol-1), carboxylation efficiency ( $\mathrm{EC}, \mathrm{A} / \mathrm{Ci}$ ) and water use efficiency (WUE, A/E). On the other hand, the indexes of chlorophylls $a, b$ and total were obtained by portable chlorophyll meter (ClorofiLOG, Model CFL 1030, Falker, Porto Alegre, RS, Brazil).

The width and length of the leaflets and the length of the petiolulus were measured with a millimeter ruler on the same leaves used for gas exchange and chlorophyll analysis. Then, plants from each treatment were randomly collected to read leaf area per plant using a leaf area meter (CID BioScience, model $\mathrm{Cl}-202$, Camas, Washington, USA).

The plant harvest occurred manually at the phenological stage $R_{8}$ (Fehr and Caviness, 1977), in a useful area of two linear meters of the three central lineages of the plot. During the harvest, four plants per plot were randomly collected for the evaluation of yield components: plant height $(\mathrm{cm})$, height of first pod insertion in the main stem $(\mathrm{cm})$, number of pods and grains per plant and number of grains per pod. From the useful area, grain yield was determined, extrapolating the result to $\mathrm{kg} \mathrm{ha}^{-1}$, as well as the mass of a thousand grains, according to Brasil (2009).

\section{Statistical analysis}

Data were submitted to analysis of variance and compared in bifactorial scheme, using the Duncan Test, at 5\% probability. Pearson correlation analysis was performed for all analyzed variables. Adaptability and stability were also analyzed by Wricke's method (1965), based on grain yield. The statistical program used was Genes (Cruz, 2008).

\section{Conclusions}

Photosynthesis per unit of leaf area was higher in $\mathrm{CY} 2$ and may be related to higher stomatal conductance, higher chlorophyll index, lower transpiration and lower leaf area of plants. The lanceolate leaf cultivar showed higher grain yield, due to the higher number of grains and the greater mass of these grains, in the two crop years. In addition, it was the one that obtained lower leaf area and lower transpiration.

The genotype with the highest productive stability was NS 6006 , with triangular leaflets, but this trait does not confer greater productive potential.

\section{Acknowledgments}

To Fundação Araucária, Conselho Nacional de Desenvolvimento Científico e Tecnológico (CNPq), Coordenação de Aperfeiçoamento de Pessoal de Nível Superior (CAPES) and Universidade Tecnológica Federal do Paraná (UTFPR) for the granting of scholarships and other financial aid.

\section{References}

Ainsworth EA, Yendrek CR, Skoneczka JA, Long SP (2012) Accelerating yerld potencial in soybean: potential targets for biotechnological improvement. Plant, Cell Environ. 35(1):32-38.

Balbinot Junior AA, Oliveira MCN de, Franchini JC, Debiasi J, Zucareli C, Ferreira AS, Werner F (2018) Phenotypic plasticity in a soybean cultivar with indeterminate growth type. Pesqui Agropecu Bras. 53(9):1038-1044.

Brasil (2009) Regras para análise de sementes. Ministério de Saúde, Pecuária e Abastecimeno. Brasília. 398p.

Câmara GMS (2000) Soja: tecnologia da produção II. Piracicaba, SP. 450p.

Campos MF, Ono EO, Rodrigues JD (2010) Arquitetura de plantas de soja e a aplicação de reguladores vegetais. Pesqui. Apl. Agrotec. 3(1):153-159.

Castro PRC, Kluge RA, Sestari I (2008) Manual de fisiologia vegetal: fisiologia dos cultivos. 1. ed. Piracicaba, SP.

Catuchi TA, Guidorizzi FVC, Guidorizi KA, Barbosa AM, Souza GM (2012) Respostas fisiológicas de cultivares de soja à adubação potássica sob diferentes regimes hídricos. Pesqui Agropecu Bras. 47(4):519-527.

Chavarria G, Durigon MR, Klein VA, Kleber H (2015) Restrição fotossintética de plantas de soja sob variação de disponibilidade hídrica. Ciênc Rural, 45(8):1387-1393.

Chen Y, Nelson RL (2004) Evaluation and classification of leaflet shape and size in wild soybean. Crop Sci. 44:671677.

Corrêa, STR (2008) Adaptação do modelo LINTUL (light Interception and utilization) para estimação da produtividade potencial da cultura de soja. Dissertação (Mestrado em fitotecnia) - Universidade de São Paulo, Escola Superior de Agriculura "Luiz de Queiroz", Piracicaba. 94p.

Cruz SCS, Sena-Junior DG, Santos DMA, Lunezzo LO, Machado CG (2016) Cultivo de soja sob diferentes densidades de semeadura e arranjos espaciais. Rev Agric Neotropical, 3(1):1-6.

Cruz, CD (2008) Programa Genes: Diversidade Genética. Editora UFV:Viçosa. 278p.

Embrapa - Empresa Brasileira de Pesquisa Agropecuária. Centro Nacional de Pesquisas de solo (2006) Sistema brasileiro de classificação de solos. 2.ed. Embrapa: Rio de Janeiro. 306p.

Fehr WR, Caviness CE (1977) Stages of soybean development. Ames: Yowa State University of Science and Technology, 11 p. (Special Report 80).

Franceschi L, Benin G, Marchioro VS, Martin TN, Silva RR, Silva CL (2010) Métodos para análise de adaptabilidade e estabilidade em cultivares de trigo no estado do Paraná. Bragantia. 69(4):797-805.

Gai Z, Zhang J, Li C (2017) Effects of starter nitrogen fertilizer on soybean root activity, leaf photosynthesis and grain yield PLoS ONE, 12(4):1-15. 
Gebiomet. Dados climáticos DV/FB 2015-2016. Available in <http://www. gebiomet.com.br/downloads.php> Access in June 2018.

Huang F, Gan Y, Zhang D, Deng F, Peng J (2018) Leaf Shape Variation and Its Correlation to Phenotypic Traits of Soybean in Northeast China. Proceedings of the 2018 6th International Conference on Bioinformatics and Computational Biology, 40-45, 2018.

lapar. Cartas Climáticas do Estado do Paraná (2009) IAPAR: Londrina. Available in <http://www.iapar.br/pagina984.html> Access in May 2018.

Jeong N, Suh SJ, Kim MH, Lee S, Kim HS, Jeong SC (2012) $L n$ Is a Key Regulator of Leaflet Shape and Number of Seeds per Pod in Soybean. Plant Cell. 24:4807-4818.

Jiang CD, Gao HY, Zou Q, Jiang JM, Li LH (2006) Leaf orientation, photorespiration and xanthophyll cycle protect young soybean leaves against high irradiance in field. Environ Exp Bot. 55:87-96.

Krisnawati A, Adie MM (2017) The leaflet shape variation from several soybean genotypes in Indonesia. Biodiversitas. 18(1):359-364.

Kume A, Akitsu T, Nasahara KN (2018) Why is chlorophyll $b$ only used in light-harvesting systems? J. Plant Res. 131(6):961-972.

Lacerda CF (2007) Relações solo, água, planta em ambientes naturais e agrícolas no Nordeste brasileiro. Departamento de Engenharia Agrícola. Universidade Federal Rural de Pernambuco. Recife. 79 p. Available in $<$ http://portais.ufg.br/up/68/o/APOSTILA__RELA_ES_SOLOS_GUA_PLANTA.pdf> Access in April 2019.

Liu F, Jensen CR, Andersen MN (2003) Hydraulic and chemical signals in the control of leaf expansion and stomatal conductance in soybean exposed to drought stress. Funct Plant Biol. 30(1):65-73.

Lopes NF, Lima MGS (2015) Fisiologia da Produção. Viçosa, MG. 1a. ed. UFV.

Ludwig MP, Schuch LOB, Oliveira S, Junior FJV, Lemes ES, Correa MF, Seus R (2016) Desempenho morfofisiológico de cultivares de soja de ciclo precoce sob alagamento do solo. Rev. Cultiv. Sab. 9(1):32-50.
Ludwig MP, Dutra LM, Filho OAL, Zabot L, Jauer A, Uhry D (2011) Populações de plantas na cultura da soja em cultivares convencionais e Roundup Ready. Rev Ceres. 58(3):305-313.

Medlyn BE, Kauwe MG de, Lin $Y$, Knauer J, Duursma RA, Williams CA, Arneth A, Clement R, Issac P, Limousin J, Linderson M, Meir P, Martin-Stpaul N, Winga L (2017) How do leaf and ecosystem measures of water-use efficiency compare? New Phytol. 216:758-770.

Oliveira DD, Lopes JM, Kowaleski M, Werner V (2017) Vantagens e desvantagens da aplicação de agroquímicos via aérea e terrestre. Enc. Biosfera, 14(26):714-728.

Prado EE, Hiromoto DM, Godinho VPC, Utumi MM, Ramalho AR (2001) Adaptabilidade e estabilidade de cultivares de soja em cinco épocas de plantio no cerrado de Rondônia. Pesqui Agropecu Bras. 36(4):625-635.

Purcell LC, Ball RA, Reaper JD, Vories ED (2002) Radiation use efficiency and biomass production in soybean at different plant population densities. Crop Sci. 42:172-177.

Reinhardt D, Kuhlemeier C (2002). Plant architecture. EMBO Reports. 3(9):846- 851.

Sinclair TR, Tanner CB, Bennett JM. 1984. Water-use efficiency in crop production. BioScience 34:36-40.

Sujata B, Basavaraja GT, Salimath PM (2011) Evaluation of narrow leaflet genotypes and genetic variability in segregating generation of soybean (Glycine max (L) Merrill). J. Plant Breed. 2(1):124-131.

Taiz L, Zeiger E (2017) Fisiologia vegetal. $6^{\circ}$ ed., Artemed: Porto Alegre. 759p.

Toledo NT, Muller AG, Berto JL, Marllmann CES (2010) Ajuste do modelo fototérmico de estimativa do desenvolvimento e do índice de área foliar de soja. Rev. Bras. Eng. Agric. Ambient. 14(3):288-295.

Wricke G (1965) Zur Berechnung der Ökovalenz bei Sommerweizen und Hafer. Z. Pflanzenzucht 52(2):127-138.

Yang F, Huang S, Gao R, Liu W, Yong T, Wang X, Wu X, Yang W. (2014). Growth of soybean seedlings in relaystrip intercropping systems in relation to light quantity and red:far-red ratio. Field Crop Res. 155:245-253. 